\title{
GAMBARAN PENGGUNAAN OBAT PADA HEPATITIS A PASIEN RAWAT INAP DI RUMAH SAKIT UMUM DAERAH dr. SOEDIRAN MANGUN SUMARSO WONOGIRI PERIODE JANUARI 2017 - JUNI 2019
}

\section{Overview Of The Use Of The Drugs In Hepatitis A Inpatients In General Hospital dr. Soediran Mangun Sumarso Wonogiri Period January 2017 - June 2019}

\author{
Listiana Noor Hidayati ${ }^{1 *}$, Truly Dian Anggraini ${ }^{2}$ \\ Email: listianaaldric@gmail.com \\ 1,2 Program Study D3 Farmasi,Stikes Nasional, Surakarta, Indonesia
}

\begin{abstract}
Abstrak
Hepatitis $A$ adalah penyakit infeksi pada hati yang disebabkan oleh virus hepatitis A. Jumlah kasus hepatitis A pasien rawat inap di Rumah Sakit Umum Daerah dr. Soediran Mangun Sumarso Wonogiri selama tahun 2017 - Juni 2019 sebanyak 110 pasien. Tujuan penelitian ini untuk mengetahui gambaran penggunaan obat pada pasien hepatitis A meliputi karakteristik dan pengobatan pasien. Penelitian ini merupakan penelitian non eksperimental dengan rancangan analisis deskriptif, dengan mengumpulkan informasi data melalui catatan rekam medik pasien hepatitis A yang didiagnosa periode Januari 2017 - Juni 2019. Parameter yang digunakan adalah persentase dari karakteristik pasien hepatitis A dihitung berdasarkan usia, jenis kelamin, jenis penyakit penyerta dan gambaran pengobatan pasien hepatitis $A$ meliputi jenis dan jumlah obat yang digunakan, jenis dan jumlah cairan infus yang digunakan. Hasil Penelitian menunjukan bahwa persentase berdasarkan usia pasien penderita terbanyak rentang usia $\geq 56$ tahun $(30,91 \%)$, persentase berdasarkan jenis kelamin terbanyak laki-laki $(55 \%)$, persentase berdasarkan jenis penyakit penyerta terbanyak jenis penyakit thypoid $(53,33 \%)$, persentase berdasarkan penggunaan obat yang banyak digunakan yaitu curcuma $(12,37 \%)$, dan persentase berdasarkan penggunaan cairan infus terbanyak yaitu ringer asetat $(58,78 \%)$.
\end{abstract}

Kata Kunci : Hepatitis A, Penggunaan Obat, Rumah Sakit Umum Daerah

\begin{abstract}
Hepatitis $A$ is an infectious disease of the liver caused by the hepatitis $A$ virus. Number of cases of hepatitis A inpatients at the Regional General Hospital dr. Soediran Mangun Sumarso Wonogiri during 2017 - June 2019 as many as 110 patients. The purpose of this study was to determine the description of drug use in hepatitis $A$ patients including the characteristics and treatment of patients. This research is a non-experimental study with a descriptive analysis design, by collecting data information through medical records of hepatitis $A$ patients diagnosed in the period January 2017 - June 2019. The parameters used are the percentage of the characteristics of hepatitis $A$ patients calculated based on age, sex, type of comorbidities and description of treatment of hepatitis $A$ patients including the type and amount of drug used, the type and amount of infusion fluid used. The results showed that the percentage based on the age of patients with the most age range $\geq$ 56 years $(30.91 \%)$, the percentage based on the most sexes of men $(55 \%)$, the percentage based on the types of comorbidities with most types of typhoid disease $(53.33 \%)$, the percentage based on the use of drugs that are widely used is curcuma $(12.37 \%)$, and the percentage based on the use of most intravenous fluids is ringer acetate (58.78\%).
\end{abstract}

Keywords: Hepatitis A, Drug Use, Regional General Hospital 


\section{PENDAHULUAN}

Hepatitis A adalah penyakit infeksi pada hati yang disebabkan oleh virus hepatitis A. Prevalensi infeksi yang ditandai dengan tingkatan antibody anti-HAV telah diketahui secara universal dan erat hubungannya dengan standar sanitasi/kesehatan daerah yang bersangkutan (Sulaiman,dkk, 2012). Lebih dari 75 anak di benua Asia, Afrika, dan India memiliki antibody anti-HAV pada usia 5 tahun. Sebagian besar infeksi HAV didapat didapat pada awal kehidupan, kebanyakan asimtomatik, dan anikterik. Di seluruh dunia terdapat sekitar 1,4 juta kasus hepatitis A setiap tahunnya. Menurut badan kesehatan dunia memperkirakan bahwa hepatitis A menyebabkan sekitar 7.134 kematian pada tahun 2016, terhitung $0,5 \%$ dari kematian karena virus hepatitis (WHO, 2019).

Prevalensi Hepatitis di Indonesia pada tahun 2013 sebesar 1,2\% meningkat dua kali dibandingkan Riskedas tahun 2007 yang sebesar $0,6 \%$. Prevalensi semakin meningkat pada penduduk berusia diatas 15 tahun. Jenis hepatitis yang menginfeksi penduduk Indonesia adalah Hepatitis B (21,8\%), Hepatitis A $(19,3 \%)$ dan Hepatitis C (2,5\%) (Pusdatin, 2017). Laporan yang diterima oleh Kementerian Kesehatan menunjukkan bahwa setiap tahun selalu terjadi KLB Hepatitis A. Pada tahun 2018 terjadi Kejadian Luar Biasa (KLB) Hepatitis A sebanyak 9 kali yang tersebar di 5 Provinsi, dan 8 Kabupaten/Kota (Di Kabupaten Bogor terjadi 2 kali KLB). Jumlah kasus KLB Hepatitis A pada tahun 2018 adalah 564 kasus dengan kasus tertinggi terjadi di Kota Singkawang Provinsi Kalimantan Barat 256 kasus (Pusat Data dan Informasi, 2019). Prevalensi hepatitis A pasien rawat inap di Rumah Sakit Umum Daerah (RSUD) dr. Soediran Mangun Sumarso Wonogiri mengalami peningkatan setiap tahunnya. Dimana peningkatan tersebut terjadi selama periode bulan Januari 2017 sampai bulan Juni 2019. Jumlah kasus hepatitis A pada tahun 2017 sebanyak 28 kasus, tahun 2018 sebanyak 47 kasus, dan pada tahun 2019 sampai bulan Juni sudah terjadi sebanyak 36 kasus.

Hepatitis A merupakan penyakit yang dapat sembuh sendiri sehingga dalam pengobatannya hanya bertujuan untuk meredakan gejala yang dirasakan dan umumnya dirawat secara rawat jalan sambil menghindari kegiatan fisik yang melelahkan. Pada pasien yang menjalani rawat inap adalah pasien yang memerlukan penggantian cairan tubuh, elektrolit intravena, dan dukungan nutrisi. Obat yang tidak perlu dan berpotensi hepatotoksik seharusnya dihindari selama fase akut penyakit dan ketika ada obat yang diindikasikan mengalami eliminasi di hati sebaiknya menggunakan dosis yang serendah mungkin (Alldredge, 2013). Berdasarkan uraian latar belakang tersebut perlu dilakukan penelitian dengan tujuan untuk mengetahui gambaran pengobatan pada hepatitis A pasien rawat inap di RSUD dr. Soediran Mangun Sumarso Wonogiri.

Penelitian ini diharapkan dapat memberikan suatu informasi dan ilmu pengetahuan mengenai gambaran pengobatan dan dapat digunakan sebagai evaluasi dan bahan masukan untuk meningkatkan mutu pengobatan pada pasien hepatitis A di RSUD Soediran Mangun Sumarso Wonogiri.

\section{METODE PENELITIAN}

Penelitian ini merupakan penelitian non eksperimental dengan rancangan analisis deskriptif. Pengumpulan data dilakukan secara retrospektif melalui penelusuran catatan rekam medik pasien hepatitis A pada instalasi rawat inap RSUD dr. Soediran Mangun Sumarso Wonogiri periode Januari 2017 - Juni 2019. Penelitian dilakukan di RSUD dr. Soediran Mangun Sumarso Wonogiri, sedangkan waktu penelitian dilakukan pada bulan November - Desember 2019. Populasi penelitian ini adalah pasien rawat inap dengan diagnosa hepatitis $\mathrm{A}$, yang tercatat pada lembar rekam medik di instalasi rawat inap RSUD dr Soediran Mangun Sumarso Wonogiri periode Januari 2017 Juni 2019 sebanyak 110 pasien. Dalam penelitan ini besarnya sampel diambil menggunakan jenis Nonprobability sampling dengan teknik Sampling Jenuh, yaitu teknik penentuan sampel bila semua anggota populasi digunakan sebagai sampel. Hal ini dilakukan karena penilitian yang ingin membuat generalisasi dengan kesalahan yang sangat kecil. Istilah lain sampel jenuh adalah sensus, dimana semua anggota populasi dijadikan sampel (Sugiyono, 2018). Jumlah sampel penelitian ini sebanyak 110 pasien. 


\section{HASIL DAN PEMBAHASAN}

Berdasarkan hasil penelusuran data rekam medik pada pasien dengan diagnosa hepatitis A yang menjalani rawat inap di RSUD dr. Soediran Mangun Sumarso Wonogiri. Analisis data secara deskriptif dilakukan untuk mengetahui karakteristik pasien hepatitis A dihitung berdasarkan usia, jenis kelamin, jenis penyakit penyerta dan gambaran penggunaan obat pasien hepatitis A meliputi jenis obat dan jumlah yang digunakan, jenis cairan infus dan jumlah yang digunakan, yang kemudian dianalisis melalui jumlah dan persentase, serta sajikan dalam bentuk tabel. Sampel yang digunakan sebanyak 110 pasien.

Karakteristik pasien hepatitis A meliputi jenis kelamin, usia, dan penyakit penyerta. Data yang diperoleh disajikan dalam tabel I, II, dan III. Penyakit Hepatitis A di RSUD dr. Soediran Mangun Sumarso Wonogiri paling banyak diderita pasien berada direntang usia $\geq 56$ tahun dengan jumlah pasien 34 orang $(30,91 \%)$. Hal ini disebabkan dengan bertambahnya usia, sehingga daya tahan tubuh mengalami penurunan dan berkurangnya perilaku hidup bersih dan sehat, sehingga akan rentan terinfeksi virus Hepatitis A. Hasil penelitian ini sesuai dengan Rikerdas 2018 bahwa prevalensi hepatitis berdasar diagnosis dokter menurut karakteristik, Provinsi Kalimantan Barat, dimana mengalami peningkatan seiring dengan bertambahnya usia. Selain itu, hal tersebut juga sesuai dengan Pusdatin 2014 dimana rentang usia pasien terbanyak $45-54$ tahun dan $\geq 55$ tahun. Paling banyak diderita jenis kelamin laki-laki sebanyak 60 orang (55\%) bukti bahwa laki-laki lebih rentan terkena Hepatitis A, dikarenakan laki-laki memiliki kesadaran yang kurang terhadap kesehatannya seperti lebih sering mengkonsumsi makanan di luar rumah. Menurut Pertiwi, dkk (2014) bahwa penelitian yang dilakukan oleh Firdous, dimana bahwa hasil analisis bivariat hubungan jenis kelamin dengan kejadian hepatitis $\mathrm{A}$, diketahui bahwa yang berjenis kelamin laki-laki mempunyai peluang sakit hepatitis A sebesar 1,680 kali dibanding yang berjenis kelamin perempuan. Sedangkan pasien hepatitis A yang selama menjalani perawatan ada yang terdiagnosa penyakit penyerta. Penyakit penyerta yang paling banyak adalah thypoid sebanyak 16 pasien (53,33\%). Hal ini berdasarkan dari hasil laboratorium yang dilakukan terhadap pasien dimana pemeriksaan biakan empedu ditemukan Salmonella typhii dan hasil test widal menunjukkan hasil yang positif. Hepatitis A didapatkan hasil pemeriksaan penunjang laboratorium SGOT dan SGPT yang sangat tinggi, bilirubin total melebihi batas normal, dan hasil urobilirubin urine pasien positif. Sedangkan pada thypoid ada peningkatan SGOT dan SGPT tapi tidak signifikan (Ririn, 2013). Pada penelitian ini pada pasien yang terdiagnosa penyakit penyerta thypoid terdapat gejala klinis yaitu nyeri kepala, pusing, dan demam berlangsung $>7$ hari biasanya menurun pada pagi hari dan meningkat lagi pada sore dan malam hari.

Tabel I. Karakteristik pasien berdasarkan usia pada periode Januari 2017 - Juni 2019

\begin{tabular}{ccc}
\hline Rentang Usia & Jumlah Pasien & Persentase (\%) \\
\hline$\leq 25$ & 8 & 7,27 \\
\hline $26-35$ & 18 & 16,36 \\
\hline $36-45$ & 25 & 22,73 \\
\hline $46-55$ & 25 & 22,73 \\
\hline$\geq 56$ & 34 & 30,91 \\
\hline Jumlah Pasien & $\mathbf{1 1 0}$ & $\mathbf{1 0 0}$ \\
\hline
\end{tabular}

Tabel II. Karakteristik pasien berdasarkan jenis kelamin pada periode Januari 2017 - Juni 2019

\begin{tabular}{ccc}
\hline Jenis Kelamin & Jumlah Pasien & Persentase (\%) \\
\hline Laki - Laki & 60 & 55 \\
\hline Perempuan & 50 & 45 \\
\hline Jumlah Pasien & $\mathbf{1 1 0}$ & $\mathbf{1 0 0}$ \\
\hline
\end{tabular}


Tabel III. Karakteristik pasien berdasarkan jenis penyakit penyerta pada periode Januari 2017 - Juni 2019

\begin{tabular}{ccc}
\hline Jenis Penyakit Penyerta & Pasien Penderita Penyakit Penyerta & Persentase (\%) \\
\hline Thypoid & 16 & 53,33 \\
\hline Hipertensi & 5 & 16,67 \\
\hline Diabetes Melitus & 4 & 13,33 \\
\hline Decomcardis & 2 & 6,67 \\
\hline Demam Berdarah & 2 & 6,67 \\
\hline Diare Kronik & 1 & 3,33 \\
\hline $\begin{array}{c}\text { Jumlah Pasien Penderita } \\
\text { Penyakit Penyerta }\end{array}$ & $\mathbf{3 0}$ & $\mathbf{1 0 0}$ \\
\hline
\end{tabular}

\section{Gambaran \\ Pengobatan \\ Pasien Hepatitis A}

Gambaran penggunaan obat meliputi kriteria golongan dan macam obat, serta penggunaan cairan infus. Dari hasil penelitian, bahwa pasien yang didiagnosa hepatitis A selama menjalani rawat inap di RSUD dr Soediran Mangun Sumarso Wonogiri periode Januari 2017 - Juni 2019, dimana jenis golongan obat yang paling sering dan banyak digunakan dalam proses pengobatan adalah hepatoprotektor, analgetik-antipiretik, dan gastrointestinal. Sedangkan untuk penggunaan cairan infus yang banyak digunakan adalah ringer asetat dan ringer laktat.

\section{Penggunaan Obat}

Hasil data yang diperoleh dari penelitian golongan obat hepatoprotektor paling banyak digunakan adalah curcuma $(12.43 \%)$. Golongan obat analgetikantipiretik yang paling banyak digunakan adalah metamizole (10.16\%). Golongan obat gastrointestinal yang paling banyak digunakan adalah ondancentron (9.63\%). Golongan obat ini yang banyak digunakan karena ditujukan untuk meredakan gejala yang dirasakan seperti mual, muntah, dan demam.

Curcuma merupakan termasuk jenis golongan obat Hepatoprotektor yaitu obat yang digunakan untuk melindungi fungsi hati dan kondisi lain dimana memiliki kandungan multivitamin dan mineral yang banyak. Kandungan kurkumin dalam curcuma memiliki efek sebagai antioksidan yang mampu menangkap ion superoksida (O2) sehingga mencegah kerusakan sel hepar (Florencia, 2009). Sesuai dengan penelitian Farzaei, dkk (2018) curcuma menunjukkan efek preventif dan kuratif terhadap penyakit hati, sehingga sangat dianjurkan untuk mempertimbangkan kurkumin sebagai produk alami yang aman dan efektif untuk penyakit hati, disamping itu pasien juga mendapatkan terapi obat lainnya. Metamizol merupakan obat antiinflamasi yang bekerja sebagai analgesik dan antipiretik dari kelompok turunan pirazolin. Pasien dengan gangguan hati yang diobati dengan paracetamol mengalami peningkatan konsentrasi ALT dan AST, selanjutnya konsentrasi rata-rata AST dan bilirubin secara signifikan lebih tinggi pada pasien diobati dengan asetaminofen dibandingkan dengan yang diobati dengan metamizole. Kejadian toksisitas hati lebih rendah dibandingkan dengan pirazolon lainnya. Jadi penggunaan metamizole pada gangguan fungsi hati lebih aman dibandingkan penggunaan paracetamol (Lutz, 2019). Pemberian antiemetik diperlukan bila pasien merasa mual dan muntah. Pada kasus hepatitis ini mual dan muntah disebabkan karena adanya gangguan di saraf perifer akibat adanya gangguan pada saraf otonom (N.vagus dan saraf simpatis) dan pada sel parietal gaster sehingga terjadi peningkatan produksi HCL yang bersifat iritatif. Ondancentron relatif lebih aman karena tidak menimbulkan reaksi ekstrapiramidal dan mempercepat pengosongan lambung (Agustin, 2014).

\section{Penggunaan Infus}

Hasil persentase yang diperoleh beberapa pasien yang menjalani rawat inap di RSUD dr Soediran Mangun Sumarso Wonogiri mendapatkan terapi cairan yang paling banyak digunakan adalah ringer asetat sebanyak $(58,78 \%)$ dan ringer laktat sebanyak 
(35,14\%). Pada penelitian ini pemberian cairan bertujuan untuk penggantian dan memenuhi cairan tubuh pasien yang hilang dimana penyakit hepatitis A memiliki tanda dan gejala seperti sering lelah, kehilangan nafsu makan, mual dan muntah, sehingga menyebabkan menurunnya daya tahan tubuh, kekurangan ion dan dehidrasi.

Maka sesuai hal tersebut, cairan ringer asetat paling sering atau banyak digunakan kepada pasien, sebab cairan tersebut berfungsi untuk pengobatan asidosis yang berhubungan dehidrasi dan kehilangan ion alkali dari tubuh. Asetat dimetabolisme diluar dari fungsi hati (otot) sedangkan laktat dimetabolisme di hati. Jadi, pemilihan cairan infus ringer asetat pada penelitian ini sudah tepat untuk pengganti cairan tubuh dengan gangguan fungsi hati.

\section{SIMPULAN}

Penyakit hepatitis A di RSUD dr. Soediran Mangun Sumarso Wonogiri yang paling dominan adalah pada usia $\geq 56$ tahun sebanyak 30,91\%, berdasarkan jenis kelamin terbanyak laki-laki sebanyak $55 \%$, dan berdasarkan jenis penyakit penyerta terbanyak yaitu jenis penyakit thypoid $53,33 \%$.

Jenis golongan obat yang paling sering dan banyak digunakan dalam proses pengobatan adalah hepatoprotektor (curcuma), antipiretik-analgetik (metamizole), dan antiemetik (ondancentron). Obat hepatoprotektor yang paling banyak digunakan adalah Curcuma sebanyak 12,43 $\%$, obat antipiretik-analgetik yang paling banyak digunakan adalah metamizole sebanyak $10,16 \%$, dan obat antiemetik yang paling banyak digunakan adalah ondancentron sebanyak 9,63\%. Cairan infus yang paling sering dan banyak digunakan dalam pengobatan pasien adalah ringer asetat sebanyak $58,78 \%$.

\section{UCAPAN TERIMA KASIH}

Puji syukur kehadirat Tuhan Yang Maha Esa yang telah memberikan rahmatNya sehingga penyusunan artikel ini dapat diselesaikan. Penulis tidak lupa mengucapkan terima kasih kepada Pihak RSUD dr. Soediran Mangun Soemarso Wonogiri, semua dosen dan asisten dosen Program Studi DIII Farmasi Sekolah Tinggi Ilmu Kesehatan
Nasional Surakarta, dan semua pihak yang tidak mungkin disebutkan satu persatu yang telah memberikan kontribusinya dalam membantu pelaksanaan penelitian dan penulisan artikel ini.

\section{DAFTAR PUSTAKA}

Agustin W, Nuraeni, 2014, Pola Peresepan Antiemetika Pada Penderita Dispepsia Pasien Dewasa Dan Lansia Rawat Inap di PKU Muhammadiyah Yogyakarta Periode Januari - Juni Tahun 2012, Media Farmasi Vol 11 No.2

Alldredge, B.K., Corelli, R.L., Ernst, M.E., Guglielmo, B.J., Jacobson, P.A., Kradjan, W.A., dan Williams, B.R., 2013, Koda-Kimble \& Young's Applied Therapeutics The Clinical use of Drugs, Tenth Edition, Lipincott Williams \& Wilkins, Philadelphia, United States of America

Farzei, M.H., Mahdi, Z., Fatemeh, P., Fardous, F.E., Ilias, M., Ericsson, C., Rozita, N., Seyed, M.N., Roja, R., dan Mohammad, A., 2018, Curcumin in Liver Diseases: A Systematic Review of the Cellular Mechanisms of Oxidative Stress and Clinical Perspective, Nutrients,10(7): 855

Florencia, A.W., 2009, Evaluasi Peresepan Pada Pasien Hepatitis B Kronis Di Instalasi Rawat Inap RSUP dr Sardjito Yogyakarta., Skripsi, Fakultas Farmasi Universitas Sanata Dharma, Yogyakarta.

Lutz, M., 2019, Metamizole (Dipyrone) and the Liver: A Review of the Literature, The Journal of Clinical Pharmacology,59(11):14331442

Pertiwi, A.I.P., Ramani, A., dan Ariyanto, Y., 2014, Pemetaan Risiko Hepatitis A dengan Sistem Informasi Geografis (SIG) di Kabupaten Jember Tahun 2013, e-Jurnal Pustaka Kesehatan, vol. 2 (no. 2): 365

Pusat Data dan Informasi, 2014, Situasi dan Analisis Hepatitis, Kementerian Kesehatan Republik Indonesia, Jakarta

Pusat Data dan Informasi, 2017, Situasi Penyakit Hepatitis B di Indonesia 2017, 
Kementerian Kesehatan Republik Indonesia, Jakarta

Pusat Data dan Informasi, 2019, Profil Kesehatan Indonesia 2018, Kementerian Kesehatan Republik Indonesia, Jakarta

Sugiyono, 2018, Metode Penelitian Kuantitatif, Kualitatif dan R\&D, PT Alfabet, Bandung
Sulaiman, A., Akbar, N., Lesmana, L.A., dan Noer, S., 2012, Buku Ajar Ilmu Penyakit Hati, CV Sagung Seto, Jakarta

World Health Organization, 2019, Hepatitis A. Diakses dari https://www.who.int/news-room/ factsheets/detail/hepatitis-a, diakses tanggal 24 September 2019 